\title{
Promoting Customer Engagement Behavior for Green Brands
}

\author{
Civilai Leckie ${ }^{1, *(\mathbb{D})}$, Daniel Rayne ${ }^{2}$ and Lester W. Johnson ${ }^{1}$ (D) \\ 1 Department of Management and Marketing, Swinburne University of Technology, Hawthorn 3122, Australia; \\ lwjohnson@swin.edu.au \\ 2 Department of Economics, Finance \& Marketing, Latrobe University, Melbourne 3086, Australia; \\ D.Rayne@latrobe.edu.au \\ * Correspondence: cleckie@swin.edu.au; Tel.: +61-3-9214-5891
}

Citation: Leckie, C.; Rayne, D.; Johnson, L.W. Promoting Customer Engagement Behavior for Green Brands. Sustainability 2021, 13, 8404 https://doi.org/10.3390/su13158404

Academic Editor: Alessandro M. Peluso

Received: 24 June 2021

Accepted: 22 July 2021

Published: 28 July 2021

Publisher's Note: MDPI stays neutral with regard to jurisdictional claims in published maps and institutional affiliations.

Copyright: (c) 2021 by the authors. Licensee MDPI, Basel, Switzerland. This article is an open access article distributed under the terms and conditions of the Creative Commons Attribution (CC BY) license (https:/ / creativecommons.org/licenses/by/ $4.0 /)$.

\begin{abstract}
This study aims to investigate the impact of desired self-identity, green perceived value and altruistic values on brand loyalty towards green brands (i.e., electric and hybrid cars) and the mediating role of customer engagement behavior on these relationships. Further, this study proposes that greenwashing perception, which can be defined as consumers perceiving organizations to be dishonest about their environmental claims, moderates the indirect effect of desired self-identity, green perceived value and altruistic values on brand loyalty via customer engagement behavior. Data were collected from a nationwide online survey of 170 customers who have purchased and used electric and hybrid cars. Partial least squares structural equation modeling (PLS-SEM) using Smart-PLS and PROCESS were employed to test the hypotheses. This study's findings indicate that desired self-identity, green perceived value and altruistic values positively influence consumer engagement behavior with the focal green car brands. Further, the mediating effect of customer engagement behavior on brand loyalty was generally found. Additionally, greenwashing perception was found to moderate the indirect effect of desired self-identity and altruistic values on brand loyalty via customer engagement behavior. The indirect effect of desired self-identity and altruistic values on brand loyalty via consumer engagement behavior was stronger at lower levels of greenwashing perception than at higher levels. This study offers key managerial implications on how green brands can promote customer engagement behavior and brand loyalty.
\end{abstract}

Keywords: customer engagement behavior; brand loyalty; desired self-identity; green perceived value; altruistic value

\section{Introduction}

Ambient air pollution causes immense harm to environmental health and has been attributed to approximately 3.5 million premature deaths from 2017, with the transportation sector considered one of the worst contributors to this global issue [1]. To combat this, stakeholders, including government, business, and consumers worldwide, are required to act.

Generally, consumers are demonstrating an increasing awareness of the need for a cleaner environment and how their consumption habits are causing environmental degradation [2]. Subsequently, consumers are showing a greater willingness to adopt sustainable consumption behaviors [2]. Sustainable consumption refers to individuals' acquisition, usage and disposal of goods and services, which consider the impact of ecological and socioeconomic conditions for current and future generations [3]. The study of consumer behavior relating to sustainable consumption has contributed to a better understanding of how individuals make purchase-related decisions concerning green brands. Research has suggested that consumer environmental concern is a critical motivating factor for green product consumption $[4,5]$.

Typically, consumers demonstrate a higher willingness to purchase and consume green products so long as they perceive them to be adequately trustworthy regarding their 
green performance and usefulness [6]. However, consumer expectations of green products are often impaired by perceptions of greenwashing, where consumers feel that companies' claims on the environmental functionality of their products cannot be substantiated [7]. Such perceptions raise consumer skepticism and perceived risk about the greenness and attributes of green products. Academic researchers have called for governments and organizations to provide more accurate and transparent information to promote trust and perceived value of green products and services among consumers [8,9]. In addition, marketing academics and practitioners utilize multiple strategies and tools to encourage open and active dialogue about sustainable issues with consumers [10]. One such strategy is customer engagement $(\mathrm{CE})$, which has significantly shifted both marketing and business practices in the past decade [11-14].

From an organization's view, CE refers to "the firm's deliberate effort to motivate, empower, and measure a customers' voluntary contribution to its marketing functions, beyond a core, economic transaction" [15] (p. 312). From a consumer's perspective, CE can be defined as the levels of cognitive, emotional and behavioral activity in direct interactions with an object (e.g., a brand) [16]. The focus of this current study is customer engagement behavior (CEB) with a green brand. Here, a green brand denotes "a brand which offers a significant eco-advantage over its incumbents and which is able to attract consumers who set their priority to be green in their purchases" [17] (p. 25). Nikolić et al. [18] argue that the definition of a green brand in the mobility industry should support the sustainable travel decision making of consumers by considering both positive and negative environmental attitudes and travel mode decision priorities. As such, this study defines a green brand as a brand that offers superior eco-advantage, taking into account consumer green priority and negative and positive environmental attitudes $[17,18]$.

Despite receiving vast academic attention in recent years, CE has been scantly studied in the context of sustainable consumption in general and green brands in particular [10]. Generally, there is a lack of empirical research relating to the conceptual meaning of CE and its drivers in sustainable consumption, with two notable exceptions. Piligrimienè et al. [10] proposed the internal (environmental attitudes, perceived responsibility and perceived behavioral efficiency) and external (social environment and conditions for and promotion of sustainable consumption) determinants of $\mathrm{CE}$ in a sustainable context. The authors examined overall engagement in sustainable consumption of green products without an emphasis on brands. Ullah et al. [5] investigated how car smart connectivity features, customer experience, and brand value impacted $\mathrm{CE}$ with electric car brands. Whilst providing further insight into $C E$ and sustainability, a gap is present as these studies do not explore how customer-brand relationships potentially drive CEB with brands. This is important as customers and brands can develop highly intimate and relational connections which drive their behavior [19]. Additionally, when customers become engaged with green car brands, they are more likely to continue using these green car brands and spread word-of-mouth referrals to other potential customers. Thus, an increase in green brand uptake contributes to better sustainable consumption and cleaner ecological conditions.

In addition, despite the sizeable research pointing to the importance of consumers' willingness to engage in environmental and socially related behaviors for communitybenefit [20-22], the literature still lacks empirical evidence on the role of such engagement in bridging the gap between consumer characteristics and consumers' behavior. In other words, a notable theoretical gap exists within extant literature concerning CE in green consumption where internal consumer states or characteristics have generally been ignored, despite being considered strong drivers of pro-environmental engagement [10,23]. As such, this current study aims to contribute to the limited research addressing internal drivers of CEB with green brands.

Specifically, when interacting with green brands, customers actively look for brand meanings that fit their lives and self-identity [24]. This current study focuses on desired self-identity, which can be defined as a sense of self that assists consumers to present themselves to others as the person they want to be [25]. Although self-identity has been 
substantiated as a crucial predictor of pro-environmental behavior [26], it remains largely under investigated in the context of sustainable consumption, and even less so when considering CE.

In addition, this current study also proposes that green perceived value potentially drives CEB with green brands. Prior research has suggested that perceived value is a critical determinant in maintaining enduring consumer-brand relationships [27] through promoting green satisfaction and green trust [28]. Consumer green satisfaction occurs when environmental and sustainable expectations and green needs are confirmed [29], whilst green trust occurs when consumers are willing to depend on a brand based on its credibility and ability to meet its environmental performance [29]. Furthermore, this current study contends that altruistic values potentially drive CEB with green brands. Prior research has rarely discussed the influence of altruistic values in the context of green behavior [30] and specifically CEB. This is surprising because altruistic values have been found to influence consumer ecological beliefs and purchase attitudes of eco-friendly packaged products among young Indian consumers [31], and purchases of energy-efficient appliances among Vietnamese consumers [32].

Finally, limited studies have provided evidence of the moderating role of greenwashing perception in the context of environmental purchase behavior. Extant research has shown that greenwashing perceptions negatively impact consumers' attitude and behavior toward brands [33]. The severity of such an impact can damage consumer brand advocacy and consumer loyalty, including repurchasing $[34,35]$. These brand outcomes are important because they impact levels of new customer acquisition and existing customer retention, two key goals concerned with CE.

With the above research backdrop, this current study aims to answer the following research questions: (i) what are the key internal drivers of $C E B$ and brand loyalty of green brands? and (ii) how does negative greenwashing perception moderate the indirect effects of the key internal drivers on brand loyalty through CEB?

In an attempt to answer the two research questions, this current study offers three notable contributions to the $\mathrm{CE}$, branding and green consumption literature. First, it proposes and empirically tests the key internal drivers of CEB with green brands, thereby contributing to current discussions on $C E$ in the sustainability consumption context. Second, this current study offers a theoretically-based conceptual model based on an integrative framework of the relationship marketing (RM) paradigm of brand management and consumer behavior. Third, this current study offers empirical evidence that addresses the nexus between consumers' internal states or characteristics and their CEB. This empirical evidence is essential since the research points to consumers' internal characteristics as strong drivers of their willingness to behaviorally engage with green brands [10,23], but practitioners do not have sufficient empirical evidence that can be used to guide their strategies in promoting green brands to certain consumer groups. As such, this current study's empirical findings contribute to a better understanding of how green brands can promote CEB and brand loyalty which are important outcomes for many organizations [36].

Further, testing the conceptual model with customers who have purchased and been using electric and hybrid cars is essential since the global transport sector is accountable for $24 \%$ of direct $\mathrm{CO}_{2}$ emissions and for approximately $60 \%$ of oil demand transportation from fuel combustion, while road vehicles (e.g., cars, trucks and buses) contribute to nearly $75 \%$ of transport $\mathrm{CO}_{2}$ emissions [37]. Finally, this study examines whether greenwashing perception represents a boundary condition.

The findings generated from this study provide key managerial implications on how green brands can engage with their customers through various communication strategies. Further, this current study offers brand-related strategies for green brands that they can use to promote resonance between consumers and their brands.

The structure of this study is as follows. The next section presents the theoretical framework and hypotheses of this study. In Section 3, this study discusses the research methodology, data collection and measurement scales of the constructs. Section 4 presents 
data analysis results. Finally, this study concludes with a discussion of the main findings, implications, research limitations, and future research.

\section{Theoretical Background}

\subsection{Theoretical Framework}

This current study employs the integrative framework of the RM paradigm of brand management and consumer behavior to support the proposed conceptual model. Consumers and brands can establish relationships similar to personal human relationships [24,38]. This notion of a strong and intimate consumer-brand relationship is supported by Belk [39], who noticed that the relationship between individuals and their possessions contributes to their sense of self, identity and social relationships. In addition, consumers play an active role in co-creating brand meaning and value through collaboration in the exchange relationship with admired brands [40]. Previous studies through the RM lens conceptualized consumerbrand relationships as being particularly interactive, experiential, and co-creative [11].

Viewed from consumer behavior concepts (i.e., the self-concept and self-image), actual self-identity and desired self-identity are often studied together. The actual self represents the reality of how an individual perceives his/herself, while the ideal self relates to the ideal version of what an individual aspires to become [41]. Consumers tend to maintain consistency among various self-representations. When discrepancies among self-concepts occur, individuals are motivated to change in the direction of the desired self [42]. As such, this current study focuses on desired self-identity. In the context of a corporate brand and its relationship with employees, Helm et al. [43] found that when employees feel the congruity between the corporate brand and their ideal self, they tend to display brand pride and self-esteem. This current study further argues that the self-expressive nature of green consumption allows customers to build and strengthen their self-identity. Green brands reflect a symbolic image instrumental to customer identity construction and preservation [44].

In addition to desired self-identity, perceived value is also found to be an essential ingredient in consumer-brand relationships [27]. In the context of green consumption, researchers have substantiated that green perceived value drives self-brand connection, green satisfaction and green trust [28,45]. When customers feel that green brands offer value by allowing them to address their green needs, while providing a favorable customer experience, they tend to display high CEB with green brands [5]. Furthermore, personal values (e.g., altruistic values) have been identified as guiding principles in an individual's life in forming beliefs, attitudes and behaviors across a wide range of contexts [46]. Allen and $\mathrm{Ng}$ [47] argued that personal values directly influence consumer product choices when they attend to the symbolic meaning of products. As suggested by the findings of Policarpo and Aguiar [4], customers purchase hybrid cars because self-expressive benefits of hybrid cars as green products allow them to address their environmental concern.

Based on the above theoretical grounding, this current study posits that desired self-identity, green perceived value and altruistic values potentially drive CEB, which subsequently influence brand outcomes, such as brand loyalty. The current study's proposed conceptual model is shown in Figure 1 below. 


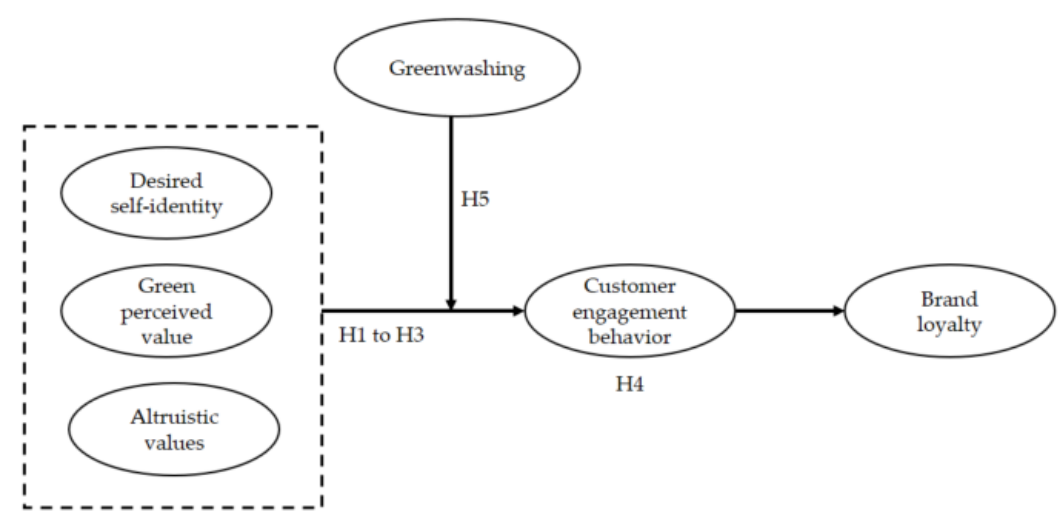

Figure 1. The proposed conceptual model.

\subsection{Customer Engagement (CE)}

Although researchers have given divergent definitions of CE, Nyadzayo et al. [48] have concluded that CE can be broadly conceptualized as either a psychological state [49] and behavioral manifestation [50] or both [51]. For example, Brodie et al. [11] (p. 260) suggested that CE represents "a psychological state that occurs by virtue of interactive, co-creative customer experience with a focal agent/object (e.g., a brand) in focal service relationships." From a behavioral perspective, van Doorn et al. [50] (p. 254) focused on CEB which can be defined as "a customer's behavioral manifestations that have a brand or a firm focus, beyond purchase, resulting from motivational drivers." With a brand as a focal object of CE, Hollebeek et al. [12] (p. 617) defined customer brand engagement as "a customer's motivationally-driven, volitional investment of focal operant resources (including cognitive, emotional, behavioral and social knowledge and skills), and operand resources (e.g., equipment) into brand interactions in service systems." Despite these various conceptualizations, this current study focuses on CEB. CEB denotes "the nontransactional and sustained involvement of customers with a brand" [5] (p. 204). This conceptualization is consistent with Harmeling et al. [15] (p. 314), who underline that "a behavioral conceptualization of customer engagement better captures its implicit and explicit meaning." Additionally, Leckie et al. [52] suggested that a brand as an engagement object is the most often studied in marketing.

CE reflects affective customer-brand relationships, which can manifest into various behaviors. Customers display their engagement behavior with focal brands by providing positive word-of-mouth referrals, giving feedback and assisting other users of the focal brands [13]. CE can also lead to customer influence over others concerning the focal brands through social media channels and provide an avenue for feedback to the brands from the customers [13].

\subsection{Hypotheses Development}

Desired self-identity denotes a sense of self that assists consumers to present themselves to others as the person they want to be and makes consumers look and feel the way they want to look and feel [25]. It is similar to the ideal self-image, reflecting a set of characteristics that an individual ideally would like to possess [53]. Self-identity can enable a movement towards or away from conforming according to how individuals perceive themselves and want to be perceived [54]. Often, consumers utilize emblematic consumption to graciously craft their desired self-image [55]. One way to do so is to consume products with symbolic value and social meanings, assisting individuals in addressing personal and social needs such as self-expression and outer-directed self-esteem [55,56]. Prior studies [25] have substantiated that customers are more likely to identify with brands that have an image congruent with their own actual and desired identities. To outwardly express their desired self-identity, customers will actively engage in word-of-mouth communication about the brands as a means of enhancing this image [57]. According to Aaker [58], consumers often use brands as a means of self-expression. Therefore, the more consumers do so, the higher 
likelihood it is for them to partake in engagement behaviors such as advocating on behalf of the brand $[59,60]$.

Furthermore, in consumer-brand relationships, the integration of actual self-identity, desired self-identity and life meaning, and intrinsic rewards represents the self-brand integration [25] concept. Drawn from self-expansion theory [61], self-brand integration indicates that consumers call upon brands as a resource to build their identity to help achieve their intrinsic goals [62,63]. Nyadzayo et al. [48] found that when customers believe that their mobile phone brands have images, personalities, and meanings congruent with their inner and social selves, they tend to display high customer brand engagement.

In addition, previous studies have identified a link between self-identity and environmental interest $[64,65]$. The relationship between self-identity and consumer engagement in a pro-environmental context is evidenced by Kadic-Maglajlic et al. [23], who found that young consumers that identify as pro-environmental are more willing to engage in pro-environmental behavior. In the context of green corporate social responsibility (CSR) action, Chuah et al. [62] found that environmentally conscious customers are more likely to integrate a particular CSR cause into their self-schema, thereby displaying higher CEB.

Based on Sirgy's [41] congruity theory and previous empirical studies above, this current study argues that customers purchase and use focal green brands as a tool to signal their identities when they feel that the brand image is congruent with their desired selfschemas. Thus, focal green brands are integrated into their desired self-identity, leading to thoughts about and actions towards these brands, such as purchasing from the brand or engaging in brand advocacy $[25,62]$. Therefore, it is proposed that:

Hypothesis 1 (H1). Desired self-identity is positively related to customer engagement behavior.

Perceived value is a fundamental element in enduring consumer-brand relationships [27]. For consumers, value derived from interaction with a brand is ubiquitous throughout their decision-making process [65]. That is, customers must feel they are receiving a sense of value for them to continue along the decision-making process. The consequences of a perceived lack of value can often result in customers reassessing their needs or switching to a competitor's offering. To counteract these potentially negative outcomes, brands attempt to shape customer perceptions of value by providing various market offerings [65]. This is also because perceived value is seen as a key antecedent to post-purchase behavior such as word-of-mouth referral [66].

The service-based literature provides empirical evidence for a link between perceived value and customer advocacy engagement. For example, in a recent study, Jones et al. [67] found evidence that consumers who perceived value from the service tend to spread wordof-mouth referrals for service brands. Furthermore, in the context of service innovation, Leckie et al. [52] found that perceived value of innovative services leads to CEB.

In the green consumption literature, the concept of green perceived value is receiving increasing academic attention [65]. Green perceived value is "a consumer's overall appraisal of the net benefits of a product or service between what is received and what is given based on the consumer's environmental desires, sustainable expectations, and green needs" [7] (p. 505). It represents a set of attributes associated with the environmental value of green products [68]. Consumers subjectively evaluate the green perceived value of a green product based on their green desires, expectations, and needs [45]. Prior research has shown that such an evaluation can manifest into affective and behavioral responses towards the brand, including purchase intentions and behavioral loyalty such as spreading positive word-of-mouth [28]. For example, extant research has shown that perceived green value has led to customer satisfaction, trust, loyalty and repurchase intention [28]. Further, Policarpo and Aguiar [4] found that consumers with environmental concerns tend to purchase hybrid cars since consumers can obtain self-expressive benefits and express a higher perception of value from buying green products.

In their study, Koller et al. [65] further highlighted the perceived value to loyalty link in a green context where consumers who view focal brands as providing green value are 
more likely to engage in advocacy behaviors. Given the relationship found in previous studies concerned with perceived green value and consumer-led outcomes, this study posits that green perceived value can affect CEB with the focal green brands. This aligns with Lin et al. [45], who found that customers that derive value from their green purchase are more likely to demonstrate favorable outcomes resulting from such perceived value, including advocacy, influencing and feedback behaviors. The findings of previous sustainability research also demonstrate that perceived value of waste sorting leads to partaking in engagement activities [69]. Thus, the following is proposed:

Hypothesis 2 (H2). Green perceived value is positively related to customer engagement behavior.

Altruistic values can be defined as "... the intention to benefit others as an expression of internal values, regardless of social or motivational reinforcement" [70] (p. 257). Individuals with strong altruistic values tend to be selfless, often portraying empathy and helping behavior [71]. As such, when it comes to prosocial activities, altruism is considered a strong driver of engagement with organizations that support social causes [72].

In the context of sustainable consumption, altruistic values reflect prosocial motives that guide consumer pro-environmental behavior [46]. As a result, consumers with altruistic values tend to display high environmental consciousness and put effort into addressing environmental problems through purchasing green brands [73]. From moral norm activation theory [74], such pro-environmental behavior occurs due to moral norms that are actuated in those who believe that poor environmental conditions threaten others [75]. Subsequently, those with strong altruistic values believe that their actions can assist others or prevent harm caused by environmental damage [75].

Empirically, altruistic values have been shown to influence prosocial brand engagement. Specifically, de Morais et al. [76] found altruism to be the primary motive of customer engagement in the circular economy. Further research has shown that altruism can play a role in influencing customers to advocate on digital media channels for brands that push for societal betterment [77]. In a consumer behavior context, Hollebeek et al. [78] found that virtual consumer engagement with a FMCG brand is influenced by various altruistic sub-processes, including empathizing, assisting and mingling. More specific to green brand engagement, Panda et al. [79] found that altruism influences consumer green brand evangelism through green purchase intention. Finally, both conceptually and empirically, research has shown that altruism manifests in people spreading word-of-mouth to inform others of their experience and provide feedback as a means of engaging in helping behavior [80-82] Therefore, the following is hypothesized:

Hypothesis 3 (H3). Altruistic values are positively related to customer engagement behavior.

Brand loyalty can be defined as "the degree to which the consumer is committed to repurchase of the brand" [83] (p. 82). From Oliver [84], consumer loyalty comprises four components, cognitive, affective, conative, and action. This current study focuses on conative (behavioral intention), where consumers indicate the willingness to repurchase the brand in the future, despite the influence of both situational factors and competitor efforts to cause brand switching [84]. Brand/organization loyalty is considered one of the most critical marketing outcomes from both a practitioner and academic point of view. Consequently, brands adopt various marketing tools in an effort to achieve brand loyalty, including attempts to stimulate customer brand engagement [85]. CE is considered a distinct construct from loyalty as $\mathrm{CE}$ is more concerned with behavioral outcomes developed from a connection with a brand [86].

Researchers have shown the positive effect between customer brand engagement and loyalty, e.g., $[52,87]$. That is, customers who are engaged with a firm will be likely to commit to particular actions that demonstrate support for the firm [87], such as repurchase intent [62]. Once formed, CEB developed from a firm's prosocial activities often leads to customer loyalty [87]. In recent sustainability literature, Chuah et al. [62] demon- 
strate that sustainable CEB mediates the relationship between self-brand integration and customer loyalty.

Evidence of the mediating role of $\mathrm{CEB}$ has been found in existing consumer behavior research. Specifically, Nyadzayo et al. [48], employed customer-based brand equity as a theoretical lens to investigate the mediating role of customer brand engagement on the relationships between brand trust, brand satisfaction and self-expressive brand and brand evangelism. The authors contended that brand trust, brand satisfaction and selfexpressive brand represent the meaning, feeling, and evaluation customers have with the focal brands. Thus, strong customer-brand relationships promote customer active engagement or resonance with the focal brands, resulting in brand loyalty and equity [88].

CEB as a mediating variable on purchase behavior and loyalty extends to brands who are considered socially or environmentally conscious [87]. For example, in recent sustainability literature, Chuah et al. [62] demonstrated that green CEB mediates the relationship between self-brand integration, as a multi-dimensional construct consisting of desired-selfidentity and customer loyalty. de Morias et al. [76] found a similar relationship where CEB mediated the role between altruistic values and green brand buying. Whilst the mediating effect of CEB between green perceived value and loyalty is yet to be empirically examined, one can theorize this outcome. This is based on previous consumer behavior literature demonstrating that CEB mediates the role of perceived value and brand loyalty [52]. From the above research findings, the following hypothesis is proposed:

Hypothesis 4 (H4). Customer engagement behavior mediates the relationship between (a) desired self-brand integration, (b) green perceived value and (c) altruistic values and customer loyalty.

Greenwashing is considered an organizational malpractice where firms are dishonest about their green marketing practices in making unconfirmed and fallacious claims about the green functionality of their products $[45,89]$. For example, a firm may make a claim that their product serves the environment when in actuality, it harms the environment, or may adopt counterintuitive CSR activities that move away from their core business, such as a fuel company investing in environmental measures [90]. Consumers may find it challenging to evaluate brand greenness since some green brands can make dubious claims concerning their environmental impacts. When consumers view brands as disingenuous in their environment functionality, greenwashing perception occurs. As such, perceptions consumers hold of the authenticity of a brand's green claims can be influential in their decision making. Prior research has substantiated that the impact of greenwashing can be far-reaching, with long-term market effects. For example, greenwashing can cause customer confusion and create doubt, distrust and cynicism about purchasing green products [91].

Addressing a gap in existing research, this current study posits that greenwashing perception potentially moderates the impact of desired self-identity, green perceived value and altruistic values on brand loyalty via CEB of the focal green brands. A few studies have empirically investigated the moderating role of greenwashing perception in the context of environmental purchase behavior. For example, Bulut et al. [92] found greenwashing perception to moderate the relationship between environmental concern and green behavior. Jog and Sinhal [93] reinforce the moderating role of greenwashing on green purchase behavior and its antecedents-receptiveness to green advertising, personal norms and environmental consciousness. In a similar vein, Lin et al. [45] discovered that when consumers feel high perceived risks generated from uncertainties surrounding the green claims of those green offerings, they report weaker influences of functional and affective product benefits on green brand image.

Based on these findings in previous studies concerned with the role of greenwashing, this current study proposes that customers are more likely to move away from focal green brands as part of their desired self-identity if they perceive the brand to be making false claims regarding environmental impacts. Similarly, customers may also feel that green perceived value generated from focal green brands diminishes if such brands are engaging in greenwashing practices. Finally, consumers with strong altruistic values are likely to feel 
that greenwashing practices of focal green brands are in sharp contrast to their personal values, and thus are less likely to commit to these brands by disengaging with them. In other words, when customers perceive the focal green brands to be actively practicing greenwashing, they are more likely to develop negative feelings towards such brands [30], subsequently diminishing the effects of desired self-identity, perceived green value, and altruistic values on brand loyalty via CEB. Based on this, the following is hypothesized:

Hypothesis 5 (H5). Greenwashing perception moderates the indirect effects of (a) desired selfidentity, (b) green perceived value and (c) altruistic values on brand loyalty via customer engagement behavior, such that the indirect effects are stronger at lower levels of greenwashing perception than at higher levels.

\section{Method}

\subsection{Data Collection}

This study used an online survey to collect data. We employed a reputable panel database company that has access to a nationwide sampling frame of owners of electric and hybrid cars in Australia. The first filter question probed the respondents whether they have purchased any electric or hybrid car in the past two years to qualify the respondents. Only the respondents who did so were allowed to proceed to the next question, which asked the respondents to write down the brand name and model of the car. If respondents had purchased more than one electric or hybrid car in the past two years, they were informed to focus on the brand they had purchased last. The brand name of the selected car was then auto-filled for the remaining questions in the survey.

A total of 170 respondents completed the survey. The demographic profile of the respondents consisted of males $(48.2 \%)$ and females (51.8\%). In terms of age, they were $18-24$ years old $(7.1 \%), 25-34$ years old $(45.9 \%), 35-44$ years old $(25.9 \%), 45-54$ years old $(5.9 \%), 55-64$ years old $(5.9 \%)$, and 65 years and older (4.7\%). Most had a Bachelor's degree $(55.3 \%)$, some had a diploma / certificate $(16.5 \%)$, postgraduate degree $(18.8 \%)$, high school $(7.6 \%)$, and other $(1.8 \%)$. The majority of the respondents had a household income of 110,000 dollars and greater $(41.7 \%)$. Table 1 shows the demographic profile of the sample.

Table 1. Sample profile.

\begin{tabular}{cccc}
\hline Demographic Variable & Item & Frequency & Percentage \\
\hline \multirow{2}{*}{ Gender } & Female & 88 & 51.8 \\
& Male & 82 & 48.2 \\
\hline \multirow{2}{*}{ Age } & 18 to 24 & 12 & 7.1 \\
& 25 to 34 & 78 & 45.9 \\
& 35 to 44 & 44 & 25.9 \\
& 45 to 54 & 10 & 5.9 \\
& 55 to 64 & 10 & 5.9 \\
& 65 and above & 16 & 9.4 \\
\hline \multirow{3}{*}{ Household income } & Under $\$ 30,000$ & 8 & 4.7 \\
& $\$ 30,000$ to $\$ 49,999$ & 6 & 12.9 \\
& $\$ 50,000$ to $\$ 69,999$ & 22 & 15.9 \\
& $\$ 70,000$ to $\$ 89,999$ & 27 & 16.5 \\
& $\$ 90,000$ to $\$ 109,999$ & 28 & 18.8 \\
& $\$ 110,000$ to $\$ 129,999$ & 32 & 22.9 \\
& $\$ 130,000$ and greater & 39 & 4.7 \\
\hline & Prefer not to say & 8 & 1.8 \\
& No degree & 3 & 7.6 \\
& High school & 13 & 16.5 \\
& Diploma/Certificate & 28 & 55.3 \\
& Bachelor's degree & 94 & 18.8 \\
\hline
\end{tabular}




\subsection{Measures}

Multi-item measures, using a seven-point scale anchored on ' 1 ' = strongly disagree to ' 7 ' = strongly agree were adopted from previous literature and adapted to suit this study's context. Two academic experts were invited to assess how well the instrument represented the constructs in this study, and thus content validity (face validity) was established. Additionally, a pretest (soft launch) was undertaken with 50 respondents. Then, preliminary checks such as sample demographics and exploratory factor analysis were conducted, and no significant issues were identified.

In measuring desired self-identify, the three-item scale by Chuah et al. [62] was adopted. The scale captures the extent to which the focal brands are able to make consumers look and feel the way they want to look and feel. Green perceived value was adapted from Lin et al. [45]. The three-item scale measures the customer evaluation of the focal brands net benefits from what is received and what is given based on their environmental desires, sustainable expectations, and green needs [7]. Altruistic values were assessed using three items from Saleem et al. [71] that reflect the intention to benefit others as an expression of internal values by using the focal brands.

Next, we measured CEB using the scale by Ullah et al. [5], who developed their items from Pansari and Kumar [13] and Brüggen et al. [94]. The scale captures the extent to which customers get involved with the focal brands by displaying behaviors such as positive word-of-mouth, recommendations and giving feedback. Brand loyalty was assessed using three items adapted from Carroll and Ahuvia [83]. The measurement items and psychometric properties for all constructs are provided in Table 2.

Table 2. Measures of constructs and their psychometric properties.

\begin{tabular}{|c|c|}
\hline Item & Factor Loading \\
\hline $\begin{array}{c}\text { Desired self-identify (DSI) }(\alpha=0.884, \mathrm{CR}=0.928, \mathrm{AVE}=0.811) \\
\text { This brand makes me look the way I want to look. } \\
\text { This brand is able to make me feel the way I want to feel. } \\
\text { This brand reflects how I want to be seen. }\end{array}$ & $\begin{array}{l}0.906 \\
0.894 \\
0.902\end{array}$ \\
\hline $\begin{array}{l}\text { Green perceived value (GPV) }(\alpha=0.855, \mathrm{CR}=0.912, \mathrm{AVE}=0.775) \\
\text { This brand's environmental functions provide very good value for me. } \\
\text { This brand has more environmental benefits than other brands. } \\
\text { This brand is more environmentally friendly than other brands }\end{array}$ & $\begin{array}{l}0.867 \\
0.871 \\
0.902\end{array}$ \\
\hline $\begin{array}{l}\text { Altruistic value }(\mathrm{AV})(\alpha=0.866, \mathrm{CR}=0.918, \mathrm{AVE}=0.798) \\
\text { Pollution generated here harms people all over the earth. } \\
\text { The effects of pollution on public health are worse than we realize. } \\
\text { Environmental protection will help people have a better quality of life. }\end{array}$ & $\begin{array}{l}0.882 \\
0.918 \\
0.863\end{array}$ \\
\hline $\begin{array}{l}\text { Customer engagement behavior (CEB) }(\alpha=0.848, \mathrm{CR}=0.899, \mathrm{AVE}=0.690) \\
\text { I say positive things about this brand to others. } \\
\text { I encourage friends and relatives to buy and use this brand. } \\
\text { I recommend this brand to someone who seeks my advice. } \\
\text { I provide feedback about my experiences with this brand to its firm. }\end{array}$ & $\begin{array}{l}0.876 \\
0.877 \\
0.847 \\
0.713\end{array}$ \\
\hline $\begin{array}{l}\text { Brand loyalty (BL) }(\alpha=0.848, \mathrm{CR}=0.907, \mathrm{AVE}=0.765) \\
\text { Compared to other brands, this is the only brand that I will buy. } \\
\text { If this brand is not available, I will postpone buying. } \\
\text { I will 'do without' rather than buy another brand. }\end{array}$ & $\begin{array}{l}0.850 \\
0.880 \\
0.894\end{array}$ \\
\hline $\begin{array}{l}\text { Greenwashing (GW) }(\alpha=0.915, \mathrm{CR}=0.938, \mathrm{AVE}=0.791) \\
\text { This brand misleads with words in its environmental features. } \\
\text { This brand misleads with visuals or graphics in its environmental features. } \\
\text { This brand possesses a green claim that is vague or seemingly un-provable. } \\
\text { This brand leaves out or masks important information, making the green claim sound better than it is. }\end{array}$ & $\begin{array}{l}0.861 \\
0.912 \\
0.909 \\
0.873\end{array}$ \\
\hline
\end{tabular}




\section{Data Analysis and Results}

When testing a conceptual model using structural equation modeling (SEM), there are two methods: (1) covariance-based SEM and (2) variance-based SEM. Many scholars have discussed the differences between the two methods, e.g., [95,96]. When evaluating a theory-based model, the covariance-based SEM is recommended [97]. This current study employs a variance-based method or Partial least squares (PLS) SEM because of the following reasons. First, this study intends to test the hypothetical model from a prediction perspective [98]. Second, PLS-SEM has fewer restrictions regarding sample size and residual distributions. Due to a small population of electric and hybrid cars (only 23,000 electric vehicle registrations in Australia-Motor Vehicle Census [99]), the sample size of this current study $(\mathrm{n}=170)$ is restricted but acceptable for PLS-SEM [100]. In addition, Hair et al. [101] provide a guideline for the sample size for PLS-SEM. From the current's study conceptual model shown in Figure 1, there are three independent variables in the model. As a result, a minimum of 103 observations is needed to achieve a statistical power of $80 \%$ to detect the $R^{2}$ value of at least 0.10 at a $5 \%$ significant level [101]. As such, this study's sample size of 170 is deemed sufficient for the use of PLS-SEM.

To analyze the data, this current study used Smart PLS 3.3.3 software. Following Hair et al. [98] and Anderson and Gerbing [102], this current study first examined the measurement model in terms of reliability and validity assessments. Then, the structural model was assessed to test the proposed hypotheses.

\subsection{Measurement Model}

An overall CFA consisting of all items loading on their respective constructs was analyzed. From Table 2, convergent validity and item reliability were supported as all factor loadings were significant and higher than the recommended level of 0.70 [98]. Next, internal reliability was established since Cronbach's $\alpha$ ranged from 0.848 to 0.915 and composite reliabilities (CRs) were from 0.899 and 0.938 . The lowest average variance extracted (AVE) was 0.690, exceeding a minimum threshold of 0.50 [103]. Discriminant validity was established since the square roots of the AVE estimate for each construct were greater than the correlation with all other constructs, providing support for discriminant validity [103]. Table 3 shows the correlations among the constructs and the square root of the AVEs.

Table 3. Discriminant validity: correlations and the square root of AVEs.

\begin{tabular}{|c|c|c|c|c|c|c|c|}
\hline Construct & 1. & 2. & 3. & 4. & 5. & 6. & 7. \\
\hline 1. DSI & $0.901^{1}$ & & & & & & \\
\hline 2. GPV & 0.563 & 0.880 & & & & & \\
\hline 3. AV & 0.403 & 0.394 & 0.888 & & & & \\
\hline 4. CEB & 0.591 & 0.571 & 0.453 & 0.831 & & & \\
\hline 5. BL & 0.511 & 0.481 & 0.196 & 0.566 & 0.875 & & \\
\hline 6. GW & -0.388 & -0.309 & -0.321 & -0.592 & -0.402 & 0.889 & \\
\hline 7. Marker variable ${ }^{2}$ & 0.091 & 0.111 & 0.040 & 0.082 & 0.106 & 0.022 & NA \\
\hline
\end{tabular}

${ }^{1}$ The square root of the AVEs is presented diagonally and italicized. DSI = desired self-identity, GPV = green perceived value, $\mathrm{AV}=$ Altruistic values, $\mathrm{CEB}=$ customer engagement behavior, $\mathrm{BL}=$ brand loyalty and $\mathrm{GW}=$ greenwashing perception. ${ }^{2}$ "I feel frustrated when I engage in a do-it-yourself project.".

This current study presents the heterotrait-monotrait (HTMT) ratio of the correlation to further support the discriminant validity among constructs. From Table 4, it can be seen that the HTMT ratios ranged from 0.074 to 0.680 , which are much lower than the recommended cut-off value of 0.85 [104]. 
Table 4. The heterotrait-monotrait (HTMT) ratio.

\begin{tabular}{cccccc}
\hline Construct & $\mathbf{1 .}$ & $\mathbf{2 .}$ & $\mathbf{3 .}$ & $\mathbf{4 .}$ & 5. \\
\hline 1. DSI & & & & \\
2. GPV & 0.662 & & & \\
3. AV & 0.465 & 0.457 & & \\
4. CEB & 0.680 & 0.674 & 0.536 & 0.667 & \\
5. BL & 0.573 & 0.566 & 0.23 & 0.165 & 0.197 \\
6. GW & 0.074 & 0.068 & 0.07 & 0.167 \\
DSI = desired self-identity, GPV = green perceived value, AV = Altruistic values, CEB = customer engagement \\
behavior, BL = brand loyalty and GW = greenwashing perception.
\end{tabular}

Since this study used a self-administered survey, there was a risk of common method bias. To reduce common method bias, ex ante approaches were implemented. During the questionnaire design, the wording of each item was systematically examined to reduce ambiguity, and items were randomized [105]. Second, the explanatory statement assured respondents of their anonymity and confidentiality. For the procedure remedies, Harman's single-factor test was performed. Results from this test showed the single factor explained approximately 35.43 , much less than $50 \%$ of the total variance [106]. Common method variance (CMV) was further assessed using a theoretically unrelated single-item marker variable ("I feel frustrated when I engage in a do-it-yourself project"). Table 3 shows that the correlations with the marker variable were below the suggested 20 cut-off for problematic method bias [105]. The CMV-adjusted correlations were compared to the unadjusted matrix [107]. The significant correlations remained unchanged after adjusting for CMV, suggesting that CMV unlikely impacted the results of this study.

\subsection{Structural Model}

Prior to interpreting the hypothesis testing results, this study examined the collinearity among the exogenous constructs using variance inflation factor (VIF). The maximum VIF score was 1.589, which is lower than the maximum cut-off value of 3.0 [98]. The $\mathrm{R}^{2}$ values of the endogenous constructs were used to measure the explanatory power of the model. For $C E B$, the $\mathrm{R}^{2}$ value was 0.469 while the $\mathrm{R}^{2}$ value for brand loyalty was 0.324 . Given the number of exogenous variables in this current study, the $R^{2}$ values above are considered acceptable [108]. From Table 5, it can be seen that the effect sizes $\left(\mathrm{f}^{2}\right)$ for the paths from three drivers (desired self-identity, green perceived value and altruistic values) to CEB can be considered small. In contrast, the effect size for the CEB-brand loyalty path is considered large [109]. Another way to evaluate the model's predictive accuracy is to examine the predictive relevance $\left(Q^{2}\right)$ value. As seen in Table 5, desired self-identity $\left(Q^{2}=0.150\right)$ had moderate predictive relevance while green perceived value and altruistic values had weak predictive relevance [110].

From the above results, it can be concluded that the structural model achieved a satisfactory model's explanatory power and predictive power. The next step was to evaluate the statistical significance of the path coefficients. Table 5 a shows that desired self-identity was significantly related to CEB $(\beta=0.330, p<0.001)$, supporting H1. Further findings also suggest that perceived green value was significantly related to CEB ( $\beta=0.306$, $p<0.001$ ), supporting H2. Additionally, altruistic values was significantly related to CEB $(\beta=0.211, p<0.01)$, thus H3 is supported. 
Table 5. Direct and mediation results.

\begin{tabular}{|c|c|c|c|c|c|c|}
\hline (a) Direct Relationships & $\beta$ & $t$-Value & $F^{2}$ & \multicolumn{2}{|l|}{$\mathrm{Q}^{2}$} & Conclusion \\
\hline $\mathrm{H} 1 \mathrm{DSI} \rightarrow \mathrm{CEB}$ & $0.330^{* * *}$ & 3.905 & 0.130 & \multicolumn{2}{|l|}{0.150} & Supported \\
\hline $\mathrm{H} 2 \mathrm{GPV} \rightarrow \mathrm{CEB}$ & $0.306^{* * *}$ & 3.518 & 0.109 & \multicolumn{2}{|l|}{0.124} & Supported \\
\hline $\mathrm{H} 3 \mathrm{AV} \rightarrow \mathrm{CBE}$ & $0.211^{* *}$ & 2.718 & 0.068 & \multirow{2}{*}{\multicolumn{2}{|c|}{0.055}} & Supported \\
\hline $\mathrm{CEB} \rightarrow \mathrm{BL}$ & $0.572^{* * *}$ & 9.080 & 0.479 & & & \\
\hline \multirow[t]{2}{*}{$\begin{array}{l}\text { (b) Standardized Indirect Effects: } \\
\text { Bias Corrected }\end{array}$} & \multirow[t]{2}{*}{$\beta$} & \multirow[t]{2}{*}{$t$-Value } & & \multicolumn{2}{|c|}{ Bootstrap 95\% CIs } & \\
\hline & & & & Lower & Upper & \\
\hline $\mathrm{H} 4 \mathrm{a} \mathrm{DSI} \rightarrow \mathrm{CEB} \rightarrow \mathrm{BL}$ & $0.188^{* * *}$ & 3.812 & & 0.107 & 0.270 & Supported \\
\hline $\mathrm{H} 4 \mathrm{~b} \mathrm{GPV} \rightarrow \mathrm{CEB} \rightarrow \mathrm{BL}$ & $0.176^{* *}$ & 2.993 & & 0.087 & 0.276 & Supported \\
\hline $\mathrm{H} 4 \mathrm{c} \mathrm{AV} \rightarrow \mathrm{CEB} \rightarrow \mathrm{BL}$ & $0.121 *$ & 2.553 & & 0.044 & 0.200 & Supported \\
\hline
\end{tabular}

Note: $\mathrm{DSI}=$ desired self-identity, GPV = green perceived value, $\mathrm{AV}=$ Altruistic values, $\mathrm{CEB}=$ customer engagement behavior, $\mathrm{BL}=$ brand loyalty and GW = greenwashing perception; ${ }^{*} p<0.10,{ }^{* *} p<0.05$ and ${ }^{* * *} p<0.01$.

The mediation test was carried out using the non-parametric bootstrapping technique [111]. The non-parametric bootstrapping regression technique with confidence intervals (CIs) helps to circumvent statistical power problems caused by asymmetric and non-normal sampling distributions of indirect effects. The direct and mediation results are shown in Table 5. The results in Table $5 \mathrm{~b}$ provide support for $\mathrm{H} 4$. The mediated effect of desired self-identity on brand loyalty via CEB was significant $(\beta=0.188, p<0.001)$ since its CLs did not include zero. Similarly, H4b was supported as the mediated effect of green perceived value on brand loyalty via CEB was significant $(\beta=0.176, p<0.01)$. Additionally, the mediated effect of altruistic value on brand loyalty via CEB was significant $(\beta=0.121$, $p<0.05)$.

\subsection{Tests of Moderated Mediation}

This study employed the PROCESS macro, Model 7 [112] to test the moderating effect of greenwashing perception. The results are shown in Table 6. According to Romani et al. [113], moderated mediation is established when the interaction between the independent variable and moderator is significant, and the moderator is significantly related to the dependent variable.

Table 6. Moderated mediation results.

\begin{tabular}{cccccc}
\hline Y & & $\boldsymbol{\beta}$ & SE & $\boldsymbol{t}$-Value & Conclusion \\
\hline \multirow{4}{*}{ H5a CEB } & Constant & 3.053 & 0.592 & 5.154 & \\
& DSI & $0.609^{* * *}$ & 0.108 & 5.622 & \\
& GW & -0.005 & 0.129 & -0.037 & \\
& DSI $\times$ GW & $-0.063^{*}$ & 0.025 & -2.522 & Supported \\
\hline \multirow{2}{*}{ H5b CEB } & Constant & 4.101 & 0.629 & 6.556 & \\
& GPV & $0.411^{* * *}$ & 0.117 & 3.515 & \\
& GW & $-0.319^{*}$ & 0.1562 & -2.042 & Not supported \\
\hline \multirow{2}{*}{ H5c CEB } & GPV $\times$ GW & -0.002 & 0.031 & -0.057 & \\
& Constant & 3.543 & 0.725 & 4.889 & \\
& AV & 0.497 & 0.125 & 3.9856 & \\
& GW & -0.042 & 0.162 & -0.260 & Supported \\
\hline
\end{tabular}

Note: DSI = desired self-identity, GPV = green perceived value, AV = Altruistic values, CEB = customer engagement behavior, $\mathrm{BL}=$ brand loyalty and $\mathrm{GW}=$ greenwashing perception; ${ }^{*} p<0.10,{ }^{* *} p<0.05,{ }^{* * *} p<0.01$.

As shown in Table 6, the interaction between desired self-identity and greenwashing perception on CEB was significant, while CEB was found to be significantly related to brand loyalty $(\beta=0.494, p<0.001)$. In order to probe the indirect effect, the conditional indirect effects at three values (mean and mean \pm one standard deviation) of the moderator 
variable (greenwashing perception at the mean of $\mathrm{GW}=3.27$ and mean $-/ \pm$ one standard deviation-at 1.73 and 4.81 , respectively) were estimated. At low levels of greenwashing perception (1.73), the conditional indirect effect of desire self-identity on brand loyalty via CEB was significant [effect (slope) $=0.247$, bootstrap lower confidence interval $(\mathrm{LCI})=0.126$ and bootstrap upper confidence interval $(\mathrm{UCI})=0.375]$. At high levels of greenwashing perception, the conditional indirect effect of desired self-identity on brand loyalty via CEB was significant [effect (slope) $=0.150$, bootstrap LCI $=0.073$ and bootstrap UCI $=0.240$ ] . As such, it can be inferred that the indirect effect of desired self-identity on brand loyalty via $C E B$ is stronger at lower levels of greenwashing perception than at higher levels. Thus, H5a is supported. The slopes of the three values of greenwashing perception are displayed in Figure 2a.

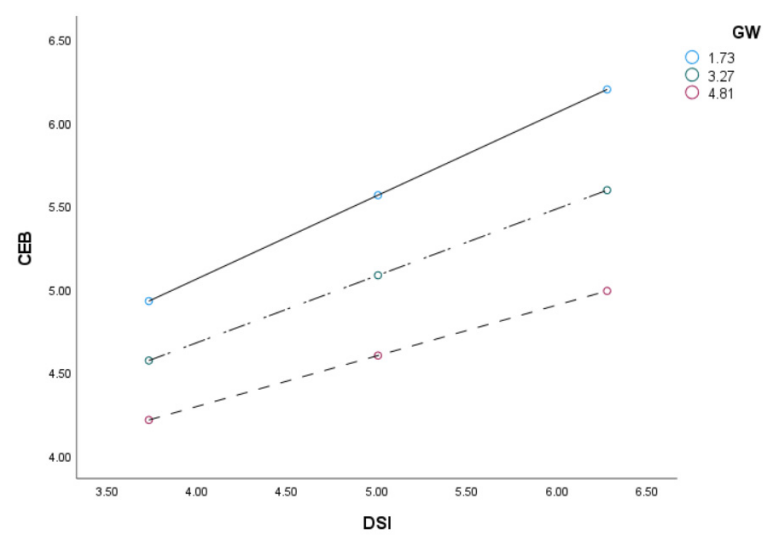

(a)

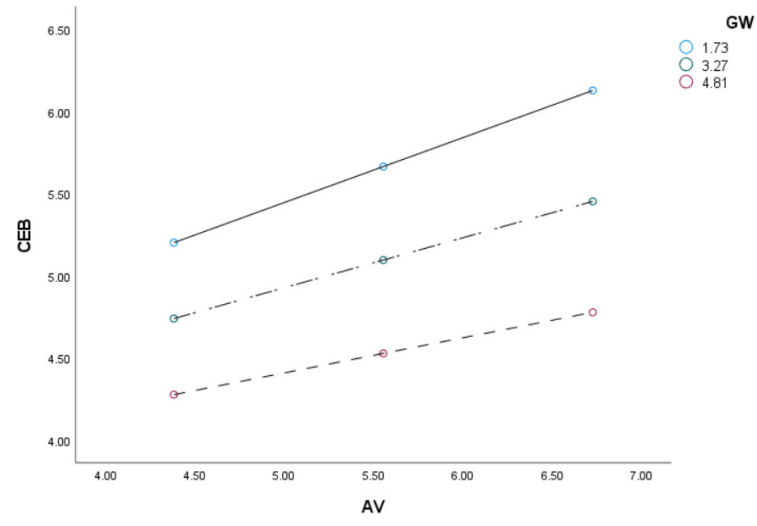

(b)

Figure 2. The indirect effects of (a) desired self-identity-DSI and (b) altruistic values-AV on brand loyalty via CEB.

From Table 6, the interaction between green perceived value and greenwashing perception on CEB was insignificant, although CEB was found to be significantly related to brand loyalty ( $\beta=0.526, p<0.001$ ). Thus, $\mathrm{H} 5 \mathrm{~b}$ is not supported. By contrast, the results of this study supported $\mathrm{H} 5 \mathrm{c}$ because the interaction between altruistic values and greenwashing perception on CEB was significant, while CEB was found to be significantly related to brand loyalty ( $\beta=0.731, p<0.001$ ). In order to probe the indirect effect, the conditional indirect effects at three values (at the mean and mean \pm one standard deviation) of greenwashing perception were estimated. At low levels of greenwashing perception (1.73), the conditional indirect effect of altruistic values on brand loyalty via CEB was significant [effect (slope) $=0.395$, bootstrap LCI $=0.231$ and bootstrap UCI $=0.559$ ] . At high levels of greenwashing perception, the conditional indirect effect of altruistic values on brand loyalty via CEB was significant [effect (slope) $=0.213$, bootstrap LCI $=0.086$ and bootstrap UCI $=0.341]$. As such, these results suggest that the indirect effect of altruistic values on brand loyalty via CEB is stronger at lower levels of greenwashing perception than at higher levels. The slopes of the three values of greenwashing perception are displayed in Figure 2b.

\section{Discussion and Implications}

\subsection{Discussion}

The transportation sector accounts for a considerable amount of global $\mathrm{CO}_{2}$ emissions [1,37]. High global $\mathrm{CO}_{2}$ emissions cause degradation of air quality and has led to approximately 3.5 million premature deaths from 2017 [1]. To make matters worse, there are a minimal number of global electric vehicles, standing at 7.2 million in 2019 [37] and approximately 23,000 vehicles in Australia. Therefore, promoting electric and hybrid cars as environmentally responsible products is critical. 
Against this backdrop, this study contributes to a better understanding of green consumption and sustainable decision making by investigating the critical drivers of $\mathrm{CE}$ with green brands. Specifically, in answering the call by previous researchers $[10,23]$ into more insight concerning the internal consumer processes that drive $\mathrm{CE}$ in green brands, this study theorized three internal antecedents (desired self-identity, perceived green value, altruistic values) to CEB and subsequent loyalty in green brands based on an integrative framework of RM and brand management [24,38,39]. Additionally, the moderating role that greenwashing perception has on these relationships was examined. To do this, data were collected from a nationwide online survey of 170 Australian customers who have purchased and used electric and hybrid cars. PLS-SEM was employed to test our theorized relationships.

The results of this current study confirm that desired self-identity, green perceived value and altruistic values have positive impacts on CEB with the focal green brands ( $\mathrm{H} 1, \mathrm{H} 2$ and $\mathrm{H} 3$ ). These results are consistent with the premise that customers can build strong and intimate relationships with the focal green brands [24,38,40]. Furthermore, our findings suggest CEB mediates the relationship between desired self-identity, green perceived value and altruistic values on brand loyalty with the focal green brands. Thus, H4 was supported. From congruity theory [41], these brands have images congruent with their desired self-identity while allowing them to address their green needs and meet personal values [55,58]. As such, customers tend to display various engagement behaviors such as word-of-mouth referral, influencing others (e.g., family and friends) to purchase the focal green brands as well as giving feedback about their experiences with the brand to the brand's firm $[5,13,94]$. Therefore, the findings of this current study suggest that CEB is a core element that transfers the impacts of internal consumer characteristics (desired self-identity, green perceived value and altruistic values) to green brand loyalty.

Moreover, our results suggest that greenwashing perception moderates the indirect effects of desired self-identity and altruistic values on brand loyalty via CEB, highlighting that the indirect effects of desired self-identity and altruistic values on brand loyalty via $\mathrm{CEB}$ are stronger at lower levels of greenwashing perception than at higher levels. Thus, H5a and $\mathrm{H} 5 \mathrm{c}$ are supported. Interestingly, our findings fail to support H5b. Our findings suggest that while green perceived value has a positive impact and greenwashing perception has a negative impact on CEB with the focal green brands, their interaction term is insignificant. These findings imply that the indirect effect of green perceived value on brand loyalty via CEB does not vary across different levels of greenwashing perception. This finding is likely explained by consumers who incorporate possible greenwashing practices when evaluating the green perceived value of the focal green car brands, resulting in indifferent engagement behavior and brand loyalty towards the focal brands.

\subsection{Theoretical Contributions}

Theoretically, this current study makes a number of contributions. Principally, this current study has addressed calls by previous researchers [10,23] for further exploration of the drivers of CEB concerning green brands, which up until now has been relatively scant. Additionally, despite consumers demonstrating a willingness to purchase from green brands or brands adopting more environmentally-friendly practices [20-22], an empirical investigation of the internal processes stimulating CEB relating to green brands remains limited.

Second, this current study provides empirical evidence that addresses the research gap on how particular consumers' internal characteristics drive consumer willingness to engage with green brands behaviorally, influencing green brand loyalty [10,23]. As such, this current study developed a theoretical model from an integrative framework incorporating RM of brand management $[24,38,39]$ and consumer behavior concepts $[41,53,55]$ (e.g., congruity theory, self-image and the self-concept). The three internal characteristics, namely, desired self-identity, green perceived value and altruistic values were proposed to drive $\mathrm{CBE}$, which in turn generally leads to consumer loyalty towards green brands. 
Third, this current study empirically presented the mechanism whereby internal consumer characteristics manifest into CEB and brand loyalty towards the focal green brands. In other words, this study's findings confirm the mediating role of CEB. As such, the findings of this study are consistent with those of the previous studies $[48,62,76]$ that $\mathrm{CE}$ is the focal mechanism through which consumer-brand relationships can influence brand outcomes.

Fourth, this study theorized and empirically tested the moderating role of greenwashing perception which has generally been measured as a mediator in extant research. By measuring greenwashing perceptions, this study has gathered deeper insight into the role of internal states on CEB in green brands and contributed to the literature by providing empirical support for greenwashing in this consumer process. As such, our findings offer a boundary condition to brand loyalty via CEB. Specifically, the findings from this study suggest that negative brand perception is an intervening variable that weakens the effects of brand-related antecedents of CE on brand outcomes (e.g., brand loyalty). Therefore, this study advances the understanding of drivers, outcomes and boundary conditions of CE in the sustainable context.

Finally, by collecting data from a sample of users who have actually made a purchase in green brands (hybrid and electric cars), we have gathered more accurate insight into engagement drawn from a customer's previous experience with a green brand. Therefore, we demonstrate that in reality, brands operating in a sector characterized by green products are able to achieve their CE and brand loyalty goals. Both are favorable business outcomes sought by many companies.

\subsection{Managerial Contributions}

Our research also offers the following managerial implications. Managers are increasingly looking for ways to engage with audiences [52]. For green brands, engagement with customers can potentially be problematic due to the skepticism commonly associated with green claims. Consequently, the findings of our study provide managers with several insights to overcome this and to engage with audiences sufficiently.

Specifically, the relationship between desired self-identity and CEB and subsequent brand loyalty suggests that managers could anthropomorphize green brands to help the brand form a stronger part of an individual's identity [63] as both the brand image and the individual's desired image align. For example, green brands could develop a spokescharacter with a virtuous image concerned with environmental degradation. Alternatively, managers could connect with well-known environmental influencers and celebrities and utilize them as brand ambassadors. Consequently, managers could use this spokesperson or brand ambassador in their advertising and other communications. The goal here would be to use narrative or storytelling techniques to show a similarity in green identity between the brand and potential customers.

Furthermore, managers may want to strengthen a customer's desired self-identity with a green brand by developing a brand membership/community where brands can engage and interact with customers. For example, hybrid and electric car brands can develop a virtual car club where customers can post images and videos of themselves using the vehicles on social media. Similarly, other green brands, for example, those operating in low-involvement product categories, can develop an analogous strategy by encouraging users to be part of their virtual brand community through communications, giveaways and exclusive offers. This can be advertised using both traditional and digital channels where environmental benefits such as water-saving are highlighted through product use.

Previous research on green consumption has indicated that altruism influences consumer green brand evangelism through green purchase intention [79]. Our findings indicate a somewhat similar path where CEB mediates the relationship between altruistic values and brand loyalty. For managers to leverage altruistic consumer values and strengthen the relationship with $\mathrm{CEB}$, we recommend employing emotional advertising appeals to highlight how consumers' altruism can be addressed through green product use. For 
example, managers could draw on 'empathy' appeals by demonstrating environmental damage non-green brands have on society or could utilize 'reaching potential' appeals to demonstrate the impact that such a purchase has on society, the environment and the public at large, helping these consumers achieve their environmental goals.

Additionally, commercial brands could partner with charity organizations to develop a cause-related marketing campaign. The logic behind this recommendation is that consumers who have a propensity for charitable giving are generally more altruistic and may view this partnership as benevolent and consequently view the commercial brand's altruistic values congruent with their own. Further, given the positive and significant effect of altruistic values on CEB and subsequent brand loyalty, it is important that managers use altruism as a significant psychographic segmentation variable and cater their communications to target consumers who possess such values. To reach these consumers, advertising and/or communication could draw on the congruency in values between a green brand and customers with higher altruism to demonstrate that both company and customer are making a positive environmental contribution.

The role of green perceived value on CEB and subsequent brand loyalty means that managers are encouraged to derive value for consumers through their customer journey. As a first step, managers should identify the various touchpoints they have with customers through their decision making process. Consequently, managers are able to strategically develop processes and communications with customers through various channels, highlighting how their brand offers green value. For example, managers can optimize transport mechanisms to reduce the delivery carbon footprint or can offer extended warranties for free for consumers who purchase green product options (e.g., purchasing a fully electric vehicle over the hybrid option). As results in this study indicate, this should continue during the post-purchase phase of the customer journey in order to develop CEB and loyalty relationships. This may take the form of social media or email communications, for example.

This study's findings relating to the moderating role of greenwashing perception on the indirect effects of the antecedents on brand loyalty via CEB indicate that customers require their green brands have a genuine green image congruent with their desired selfidentity and personal values. Consistent with the findings of past studies in sustainable consumption research e.g., [45], it is recommended that managers adopt a transparent communication approach to indicate the authenticity of their green claims and achieve subsequent brand loyalty via CEB.

Furthermore, it is important that managers avoid misleading claims concerning their environmental contribution [114]. Here, managers need to ensure that their core values and communications are consistent and that they do not exaggerate the environmental friendliness of their products. This particularly extends to managers operating in industries that can be perceived as polluters (e.g., fuel and mining), where managers should avoid superficial pro-environmental actions to avoid greenwashing perceptions. This includes managers operating in the transportation industry who have recently faced high-profile cases of misleading consumers with their green claims [115].

To summarize, managers need to be aware of the psychological states that drive CEB and brand loyalty in green brands. Our findings demonstrating the role of these internal states on CEB and our subsequent managerial contributions offer managers of green brands some insight into how to address or leverage such states.

\section{Limitations and Future Research}

This current study contains some limitations which provide avenues for future research. First, the context consisted of hybrid/electric vehicles, which can be considered high-involvement purchases. Such purchases generally require greater effort within the decision making process. Utilizing a lower-involvement context might yield varying results where consumers may perceive different levels of green products' sustainable contributions. Second, there is a limited set of antecedent variables presented in the conceptual model. 
Including other values such as biospheric and egoistic values will enable further insight into the influences on CEB generated from sustainable purchases. Finally, this study is bound by limitations commonly associated with cross-sectional research. To overcome some of these limitations, future research could examine CEB using a longitudinal study. Investigating the relationships among constructs in this current study's conceptual model across different purchase stages (pre-purchase and post-purchase) may yield insights on how CEB changes over time. Alternatively, using an experimental design, highlighting key boundary conditions (e.g., perceived environmental effectiveness) may impact the relationships between the antecedents, CEB and brand loyalty.

\section{Conclusions}

There has been a strong shift towards sustainable consumption and consideration of environmental impacts in consumer decision making [2]. To redress this, brands have altered their business and marketing practices in an attempt to meet this increasing consumer need. For example, brands now incorporate environmental sustainability decisions in their supply chains and communicate these practices to consumers via advertisements [114]. Such an approach is arguably a strategic response to calls to be more transparent with consumers and ensure that impacts on the environment are minimized. As part of this transparent strategic approach, brands are turning to CE practices [11-14] to communicate and interact with consumers concerning their green actions. However, this approach can be met with skepticism as consumers navigate the intentions of brands for developing their green practices and communicating these to their target audiences [7], as well as the authenticity of their green claims, where disingenuous claims may result in greenwashing perceptions.

For Green Brands, Understanding CEB forms the basis for promoting sustainable consumption, and contributing to the acquisition and retention of customers. Therefore, in order to prompt sustainable consumption decision making, green brands need to consider the drivers of CEB and actively strengthen their brand relationships with consumers. By encouraging consumers to use their green brands to signal their desired self-identity and altruistic values, green brands are able to develop CEB and subsequent brand loyalty. Finally, green brands must be aware of certain boundary conditions (e.g., greenwashing perceptions) that may weaken or strengthen the impact of internal states on CEB and brand outcomes and subsequently alter their marketing strategies to achieve CEB objectives.

Author Contributions: All three authors conceived and developed a conceptual framework and selected the measurement scales; C.L. collected and analyzed the data; C.L. and D.R. wrote the paper; D.R. and L.W.J. are responsible for funding the data collection; L.W.J. reviewed and edited the final draft. All authors have read and agreed to the published version of the manuscript.

Funding: This research received no external funding.

Institutional Review Board Statement: The study was conducted according to the guidelines of the Declaration of Helsinki, and approved by the Institutional Review Board (or Ethics Committee) of La Trobe University (HEC21134 04/05/2021).

Informed Consent Statement: Informed consent was obtained from all subjects involved in the study.

Data Availability Statement: The data presented in this study are available on request from the corresponding author. The data are not publicly available due to privacy reasons.

Conflicts of Interest: The authors declare no conflict of interest.

\section{References}

1. Anenberg, S.; Miller, J.; Henze, D.; Minjares, R. A Global Snapshot of the Air Pollution-Related Health Impacts of Transportation Sector Emissions in 2010 and 2015. International Council on Clean Transportation. Available online: https: / theicct.org/sites / default/files/publications /Global_health_impacts_transport_emissions_2010-2015_20190226.pdf (accessed on 13 July 2021).

2. Huang, M.H.; Rust, R.T. Sustainability and consumption. J. Acad. Mark. Sci. 2011, 39, 40-54. [CrossRef]

3. Geiger, S.M.; Fischer, D.; Schrader, U. Measuring what matters in sustainable consumption: An integrative framework for the selection of relevant behaviors. Sustain. Dev. 2018, 26, 18-33. [CrossRef] 
4. Policarpo, M.C.; Aguiar, E.C. How self-expressive benefits relate to buying a hybrid car as a green product. J. Clean. Prod. 2020, 252, 119859. [CrossRef]

5. Ullah, A.; Zhang, Q.; Ahmed, M. The impact of smart connectivity features on customer engagement in electric vehicles. Sustain. Prod. Consum. 2021, 26, 203-212. [CrossRef]

6. Wells, V.K.; Ponting, C.A.; Peattie, K. Behaviour and climate change: Consumer perceptions of responsibility. J. Mark. Manag. 2011, 27, 808-833. [CrossRef]

7. Chen, Y.S.; Chang, C.H. Enhance green purchase intentions: The role of green perceived value, green perceived risk and green trust. Manag. Decis. 2012, 50, 502-520. [CrossRef]

8. Ding, Y.; Veeman, M.M.; Adamowicz, W.L. Functional food choices: Impacts of trust and health control beliefs on Canadian consumers' choices of canola oil. Food Policy 2015, 52, 92-98. [CrossRef]

9. Lin, J.; Lobo, A.; Leckie, C. The influence of green brand innovativeness and value perception on brand loyalty: The moderating role of green knowledge. J. Strateg. Mark. 2019, 27, 81-95. [CrossRef]

10. Piligrimienè, Ž.; Žukauskaitè, A.; Korzilius, H.; Banytè, J.; Dovalienè, A. Internal and external determinants of consumer engagement in sustainable consumption. Sustainability 2020, 12, 1439. [CrossRef]

11. Brodie, R.J.; Hollebeek, L.D.; Juric, B.; Ilic, A. Customer engagement: Conceptual domain, fundamental propositions, and implications for research. J. Serv. Res. 2011, 14, 252-271. [CrossRef]

12. Hollebeek, L.D.; Srivastava, R.K.; Chen, T. S-D logic-informed customer engagement: Integrative framework, revised fundamental propositions, and application to CRM. J. Acad. Mark. Sci. 2019, 47, 161-185. [CrossRef]

13. Pansari, A.; Kumar, V. Customer engagement: The construct, antecedents, and consequences. J. Acad. Mark. Sci. 2017, 45, $294-311$. [CrossRef]

14. Beckers, S.F.; Van Doorn, J.; Verhoef, P.C. Good, better, engaged? The effect of company-initiated customer engagement behavior on shareholder value. J. Acad. Mark. Sci. 2018, 46, 366-383. [CrossRef]

15. Harmeling, C.M.; Moffett, J.W.; Arnold, M.J.; Carlson, B.D. Toward a theory of customer engagement marketing. J. Acad. Mark. Sci. 2017, 45, 312-335. [CrossRef]

16. Hollebeek, L.D. Demystifying customer brand engagement: Exploring the loyalty nexus. J. Mark. Manag. 2011, 27, 785-807. [CrossRef]

17. Grant, J. Green marketing. Strateg. Dir. 2008, 24, 25-27. [CrossRef]

18. Mamula Nikolić, T.; Pantić, S.P.; Paunović, I.; Filipović, S. Sustainable Travel Decision-Making of Europeans: Insights from a Household Survey. Sustainability 2021, 13, 1960. [CrossRef]

19. Gambetti, R.C.; Graffigna, G.; Biraghi, S. The grounded theory approach to consumer-brand engagement: The practitioner's standpoint. Int. J. Mark. Res. 2012, 54, 659-687. [CrossRef]

20. Chabowski, B.R.; Mena, J.A.; Gonzalez-Padron, T.L. The structure of sustainability research in marketing, 1958-2008: A basis for future research opportunities. J. Acad. Mark. Sci. 2011, 39, 55-70. [CrossRef]

21. Sarrami Fouroushani, P.; Travaglia, J.F.; Eikli, M.; Braithwaite, J. Consumer and Community Engagement: A Review of the Literature; Centre for Clinical Governance Research, Australian Institute of Health Innovation, University of New South Wales: Sydney, Australia, 2012.

22. Steg, L.; Vlek, C. Encouraging pro-environmental behaviour: An integrative review and research agenda. J. Environ. Psychol. 2009, 29, 309-317. [CrossRef]

23. Kadic-Maglajlic, S.; Arslanagic-Kalajdzic, M.; Micevski, M.; Dlacic, J.; Zabkar, V. Being engaged is a good thing: Understanding sustainable consumption behavior among young adults. J. Bus. Res. 2019, 104, 644-654. [CrossRef]

24. Fournier, S. Consumers and their brands: Developing relationship theory in consumer research. J. Consum. Res. 1998, 24, 343-373. [CrossRef]

25. Batra, R.; Ahuvia, A.; Bagozzi, R.P. Brand love. J. Mark. 2012, 76, 1-16. [CrossRef]

26. Dermody, J.; Hanmer-Lloyd, S.; Koenig-Lewis, N.; Zhao, A.L. Advancing sustainable consumption in the UK and China: The mediating effect of pro-environmental self-identity. J. Mark. Manag. 2015, 31, 1472-1502. [CrossRef]

27. Zeithaml, V.A. Consumer perceptions of price, quality, and value: A means-end model and synthesis of evidence. J. Mark. 1988, 52, 2-22. [CrossRef]

28. Chen, Y.S. Towards green loyalty: Driving from green perceived value, green satisfaction, and green trust. Sustain. Dev. 2013, 21, 294-308. [CrossRef]

29. Chen, Y.S. The drivers of green brand equity: Green brand image, green satisfaction, and green trust. J. Bus. Ethics 2010, 93, 307-319. [CrossRef]

30. De Groot, R.S.; Blignaut, J.; Van Der Ploeg, S.; Aronson, J.; Elmqvist, T.; Farley, J. Benefits of investing in ecosystem restoration. Conserv. Biol. 2013, 27, 1286-1293. [CrossRef]

31. Prakash, G.; Choudhary, S.; Kumar, A.; Garza-Reyes, J.A.; Khan, S.A.R.; Panda, T.K. Do altruistic and egoistic values influence consumers' attitudes and purchase intentions towards eco-friendly packaged products? An empirical investigation. J. Retail. Consum. Serv. 2019, 50, 163-169. [CrossRef]

32. Nguyen, T.N.; Lobo, A.; Greenland, S. The influence of Vietnamese consumers' altruistic values on their purchase of energy efficient appliances. Asia Pac. J. Mark. Logist. 2017, 29, 759-777. [CrossRef]

33. Polonsky, M.J.; Rosenberger, P.J., III. Reevaluating green marketing: A strategic approach. Bus. Horiz. 2001, 44, 21-30. [CrossRef] 
34. Chen, Y.S.; Huang, A.F.; Wang, T.Y.; Chen, Y.R. Greenwash and green purchase behaviour: The mediation of green brand image and green brand loyalty. Total Qual. Manag. Bus. Excell. 2020, 31, 194-209. [CrossRef]

35. Chen, Y.S.; Lin, C.L.; Chang, C.H. The influence of greenwash on green word-of-mouth (green WOM): The mediation effects of green perceived quality and green satisfaction. Qual. Quant. 2014, 48, 2411-2425. [CrossRef]

36. Leckie, C.; Nyadzayo, M.; Johnson, L.W. Customer engagement and organizational performance: A service dominant logic perspective. In Handbook of Research on Customer Engagement; Hollebeek, L.D., Sprott, D.E., Eds.; Edward Elgar: Cheltenham, UK, 2019; pp. 329-357.

37. International Energy Agency. Available online: https:/ / www.iea.org/reports/tracking-transport-2020 (accessed on 12 July 2021 ).

38. Aggarwal, P. The effects of brand relationship norms on consumer attitudes and behavior. J. Consum. Res. 2004, 31, 87-101. [CrossRef]

39. Belk, R.W. Possessions and the extended self. J. Consum. Res. 1988, 2, 139-168. [CrossRef]

40. Louro, M.J.; Cunha, P.V. Brand management paradigms. J. Mark. Manag. 2001, 17, 849-875. [CrossRef]

41. Sirgy, M.J. Self-concept in consumer behavior: A critical review. J. Consum. Res. 1982, 9, 287-300. [CrossRef]

42. DeMarree, K.G.; Rios, K.; Randell, J.A.; Wheeler, S.C.; Reich, D.A.; Petty, R.E. Wanting to be different predicts nonmotivated change: Actual-desired self-discrepancies and susceptibility to subtle change inductions. Personal. Soc. Psychol. Bull. 2016, 42, 1709-1722. [CrossRef] [PubMed]

43. Helm, S.V.; Renk, U.; Mishra, A. Exploring the impact of employees' self-concept, brand identification and brand pride on brand citizenship behaviors. Eur. J. Mark. 2016, 50, 58-77. [CrossRef]

44. Soron, D. Sustainability, self-identity and the sociology of consumption. Sustain. Dev. 2010, 18, 172-181. [CrossRef]

45. Lin, J.; Lobo, A.; Leckie, C. The role of benefits and transparency in shaping consumers' green perceived value, self-brand connection and brand loyalty. J. Retail. Consum. Serv. 2017, 35, 133-141. [CrossRef]

46. Steg, L.; De Groot, J.I. Environmental values 2012. In The Oxford Handbook of Environmental and Conservation Psychology; Clayton, S.D., Ed.; Oxford University Press: New York, NY, USA, 2012; pp. 81-93.

47. Allen, M.W.; Ng, S.H. The direct and indirect influences of human values on product ownership. J. Econ. Psychol. 1999, 20, 5-39. [CrossRef]

48. Nyadzayo, M.W.; Leckie, C.; Johnson, L.W. The impact of relational drivers on customer brand engagement and brand outcomes. J. Brand Manag. 2020, 27, 561-578. [CrossRef]

49. Dwivedi, A. A higher-order model of consumer brand engagement and its impact on loyalty intentions. J. Retail. Consum. Serv. 2015, 24, 100-109. [CrossRef]

50. van Doorn, J.; Lemon, K.N.; Mittal, V.; Nass, S.; Pick, D.; Pirner, P.; Verhoef, P.C. Customer engagement behavior: Theoretical foundations and research directions. J. Serv. Res. 2010, 13, 253-266. [CrossRef]

51. Hollebeek, L.D.; Glynn, M.S.; Brodie, R.J. Consumer brand engagement in social media: Conceptualization, scale development and validation. J. Interact. Mark. 2014, 28, 149-165. [CrossRef]

52. Leckie, C.; Nyadzayo, M.W.; Johnson, L.W. Promoting brand engagement behaviors and loyalty through perceived service value and innovativeness. J. Serv. Mark. 2018, 32, 70-82. [CrossRef]

53. Wang, J.J.; Wann, D.L.; Lu, Z.; Zhang, J.J. Self-expression through sport participation: Exploring participant desired self-image. Eur. Sport Manag. Q. 2018, 18, 583-606. [CrossRef]

54. Christensen, N.; Rothberger, H.; Wood, W.; Matz, D. Social norms andidentity relevance: A motivational approach to normative behaviour. Personal. Soc. Psychol. Bull. 2004, 30, 1295-1309. [CrossRef]

55. Wang, J.J.; Braunstein-Minkove, J.R.; Baker, T.A.; Li, B.; Zhang, J.J. Self-Branding through NFL Team Fanship: Fans' Desired Self-Image and Its Implications for Branding Practices. Sport Mark. Q. 2020, 29, 47-61. [CrossRef]

56. Park, C.W.; Jaworski, B.J.; MacInnis, D.J. Strategic brand concept-image management. J. Mark. 1986, 50, 135-145. [CrossRef]

57. De Angelis, M.; Bonezzi, A.; Peluso, A.M.; Rucker, D.D.; Costabile, M. On braggarts and gossips: A self-enhancement account of word-of-mouth generation and transmission. J. Mark. Res. 2012, 49, 551-563. [CrossRef]

58. Aaker, J.L. Dimensions of brand personality. J. Mark. Res. 1997, 34, 347-356. [CrossRef]

59. Lee, J.K.; Hansen, S.S.; Lee, S.Y. The effect of brand personality self-congruity on brand engagement and purchase intention: The moderating role of self-esteem in Facebook. Curr. Psychol. 2020, 39, 2116-2128. [CrossRef]

60. Hayes, J.L.; King, K.W. The social exchange of viral ads: Referral and coreferral of ads among college students. J. Interact. Mark. 2014, 14, 98-109. [CrossRef]

61. Aron, A.P.; Aron, E.N. Love and the Expansion of Self: Understanding Attraction and Satisfaction; Hemisphere: Washington, DC, USA, 1986.

62. Chuah, S.H.W.; El-Manstrly, D.; Tseng, M.L.; Ramayah, T. Sustaining customer engagement behavior through corporate social responsibility: The roles of environmental concern and green trust. J. Clean. Prod. 2020, 262, 121348. [CrossRef]

63. Delgado-Ballester, E.; Palazón, M.; Pelaez-Muñoz, J. This anthropomorphized brand is so loveable: The role of self-brand integration. Span. J. Mark. ESIC 2017, 21, 89-101. [CrossRef]

64. Whitmarsh, L.; O'Neill, S. Green identity, green living? The role of pro-environmental self-identity in determining consistency across diverse pro-environmental behaviours. J. Environ. Psychol. 2010, 30, 305-314. [CrossRef]

65. Koller, M.; Floh, A.; Zauner, A. Further insights into perceived value and consumer loyalty: A "green" perspective. Psychol. Mark. 2011, 28, 1154-1176. [CrossRef] 
66. Lin, C.H.; Sher, P.J.; Shih, H.Y. Past progress and future directions in conceptualizing customer perceived value. Int. J. Serv. Ind. Manag. 2005, 16, 318-336. [CrossRef]

67. Jones, C.W.; Byon, K.K.; Huang, H. Service quality, perceived value, and fan engagement: Case of Shanghai Formula One racing. Sport Mark. Q. 2019, 28, 63-76. [CrossRef]

68. Chen, S.Y. Green helpfulness or fun? Influences of green perceived value on the green loyalty of users and non-users of public bikes. Transp. Policy 2016, 47, 149-159. [CrossRef]

69. Wang, Q.; Long, X.; Li, L.; Kong, L.; Zhu, X.; Liang, H. Engagement factors for waste sorting in China: The mediating effect of satisfaction. J. Clean. Prod. 2020, 267, 122046. [CrossRef]

70. Price, L.L.; Feick, L.F.; Guskey, A. Everyday market helping behavior. J. Public Policy Mark. 1995, 14, 255-266. [CrossRef]

71. Saleem, M.A.; Eagle, L.; Low, D. Market segmentation based on eco-socially conscious consumers' behavioral intentions: Evidence from an emerging economy. J. Clean. Prod. 2018, 193, 14-27. [CrossRef]

72. Merrilees, B.; Miller, D.; Yakimova, R. Building brands through internal stakeholder engagement and co-creation. J. Prod. Brand. Manag. 2021. [CrossRef]

73. Zou, L.W.; Chan, R.Y. Why and when do consumers perform green behaviors? An examination of regulatory focus and ethical ideology. J. Bus. Res. 2019, 94, 113-127. [CrossRef]

74. Schwartz, S.H. Normative influences on altruism. In Advances in Experimental Social Psychology; Berkowitz, L., Ed.; Academic Press: New York, NY, USA, 1977; Volume 10, pp. 221-279.

75. Stern, P. Toward a coherent theory of environmentally significant behavior. J. Soc. Issues 2000, 56, 407-424. [CrossRef]

76. de Morais, L.H.L.; Pinto, D.C.; Cruz-Jesus, F. Circular economy engagement: Altruism, status, and cultural orientation as drivers for sustainable consumption. Sustain. Prod. Consum. 2021, 27, 523-533. [CrossRef]

77. Vander Shee, B.A.; Peltier, J.; Dahl, A.J. Antecedent consumer factors, consequential branding outcomes and measures of online consumer engagement: Current research and future directions. J. Res. Interact. Mark. 2020, 14, 239-268. [CrossRef]

78. Hollebeek, L.D.; Juric, B.; Tang, W. Virtual brand community engagement practices: A refined typology and model. J. Serv. Mark. 2017, 31, 204-217. [CrossRef]

79. Panda, T.K.; Kumar, A.; Jakhar, S.; Luthra, S.; Garza-Reyes, J.A.; Kazancoglu, I.; Nayak, S.S. Social and environmental sustainability model on consumers' altruism, green purchase intention, green brand loyalty and evangelism. J. Clean. Prod. 2020, 243, 118575. [CrossRef]

80. Verleye, K.; Gemmel, P.; Rangarajan, D. Managing engagement behaviors in a network of customers and stakeholders: Evidence from the nursing home sector. J. Serv. Res. 2013, 17, 68-84. [CrossRef]

81. Celuch, K.; Robinson, N.M.; Walsh, A.M. A framework for encouraging retail customer feedback. J. Serv. Mark. 2015, 29, 280-292. [CrossRef]

82. Marbach, J.; Lages, C.R.; Nunan, D. Who are you and what do you value? Investigating the role of personality traits and customer-perceived value in online customer engagement. J. Mark. Manag. 2016, 36, 502-525. [CrossRef]

83. Carroll, B.A.; Ahuvia, A.C. Some antecedents and outcomes of brand love. Mark. Lett. 2020, 17, 79-89. [CrossRef]

84. Oliver, R. Whence consumer loyalty? J. Mark. 1999, 63, 33-44. [CrossRef]

85. Parihar, P.; Dawra, J.; Sahay, V. The role of customer engagement in the involvement-loyalty link. Mark. Intell. Plan. 2019, 37, 66-79. [CrossRef]

86. Kumar, V.; Pansari, A. Competitive advantage through engagement. J. Mark. Res. 2016, 53, 497-514. [CrossRef]

87. Abbas, M.; Gao, Y.; Shah, S.S.H. CSR and customer outcomes: The mediating role of customer engagement. Sustainability 2018, 10, 4243. [CrossRef]

88. Keller, K.L. Building Customer-Based Brand Equity: A Blueprint for Creating Strong Brands; Marketing Science Institute: Cambridge, MA, USA, 2001; pp. 3-27.

89. Huang, R.; Chen, D. Does environmental information disclosure benefit waste discharge reduction? Evidence from China. J. Bus. Ethics 2015, 129, 535-552. [CrossRef]

90. De Vries, G.; Terwel, B.W.; Ellemers, N.; Daamen, D.D. Sustainability or profitability? How communicated motives for environmental policy affect public perceptions of corporate greenwashing. Corp. Soc. Responsib. Environ. Manag. 2015, 22, 142-154. [CrossRef]

91. Pomering, A.; Johnson, L.W. Advertising corporate social responsibility initiatives to communicate corporate image: Inhibiting scepticism to enhance persuasion. Corp. Comm. Int. J. 2009, 14, 420-439. [CrossRef]

92. Bulut, C.; Nazli, M.; Aydin, E.; Haque, A.U. The effect of environmental concern on conscious green consumption of postmillennials: The moderating role of greenwashing perceptions. Young Consum. 2021, 22, 306-319. [CrossRef]

93. Jog, D.; Singhal, D. Greenwashing Understanding Among Indian Consumers and Its Impact on Their Green Consumption. Glob. Bus. Rev. 2020. [CrossRef]

94. Brüggen, E.C.; Foubert, B.; Gremler, D.D. Extreme makeover: Short-and long-term effects of a remodeled servicescape. J. Mark. 2011, 75, 71-87. [CrossRef]

95. Hair, J.F.; Hult, G.T.M.; Ringle, C.M.; Sarstedt, M.; Thiele, K.O. Mirror, Mirror on the wall: A comparative evaluation of composite-based structural equation modeling methods. J. Acad. Mark. Sci. 2017, 45, 616-632. [CrossRef] 
96. Henseler, J.; Hubona, G.S.; Ray, P.A. Partial least squares path modeling: Updated guidelines 2017. In Partial Least Squares Structural Equation Modeling: Basic Concepts, Methodological Issues and Applications; Latan, H., Noonan, R., Eds.; Springer: Heidelberg, Germany, 2017; pp. 19-39.

97. Ringle, C.; da Silva, D.; Bido, D. Structural Equation Modeling with the SmartPLS. Braz. J. Mark. 2015, 13, 56-73. [CrossRef]

98. Hair, J.F.; Risher, J.J.; Sarstedt, M.; Ringle, C.M. When to use and how to report the results of PLS-SEM. Eur. Bus. Rev. 2019, 31, 2-24. [CrossRef]

99. Motor Vehicle Census, Australia. Available online: https://www.abs.gov.au/statistics/industry/tourism-and-transport/motorvehicle-census-australia/latest-release (accessed on 11 July 2021).

100. Rigdon, E.E. Choosing PLS path modeling as analytical method in European management research: A realist perspective. Eur. Manag. J. 2016, 34, 598-605. [CrossRef]

101. Hair, J.F.; Hult, G.T.M.; Ringle, C.M.; Sarstedt, M. A Primer on Partial Least Squares Structural Equation Modeling (PLS-SEM), 2nd ed.; Sage: Thousand Oaks, CA, USA, 2017.

102. Anderson, J.C.; Gerbing, D.W. Structural equation modeling in practice: A review and recommended two-step approach. Psychol. Bull. 1992, 103, 411-423. [CrossRef]

103. Fornell, C.; Larcker, D.F. Structural equation models with unobservable variables and measurement error: Algebra and statistics. J. Mark. Res. 1981, 18, 382-388. [CrossRef]

104. Henseler, J.; Ringle, C.M.; Sarstedt, M. A new criterion for assessing discriminant validity in variance-based structural equation modelling. J. Acad. Mark. Sci. 2015, 43, 115-135. [CrossRef]

105. Malhotra, N.K.; Kim, S.S.; Patil, A. Common method variance in IS research: A comparison of alternative approaches and a reanalysis of past research. J. Manag. Sci. 2006, 52, 1865-1883. [CrossRef]

106. Podsakoff, P.M.; MacKenzie, S.B.; Lee, J.Y.; Podsakoff, N.P. Common method biases in behavioral research: A critical review of the literature and recommended remedies. J. Appl. Psychol. 2003, 88, 879-903. [CrossRef]

107. Lindell, M.K.; Whitney, D.J. Accounting for common method variance in cross-sectional research designs. J. Appl. Psychol. 2001, 86, 114-121. [CrossRef]

108. Hair, J.F.; Black, W.C.; Babin, B.J.; Anderson, R.E. Multivariate Data Analysis, 7th ed.; Englewood Cliffs: Prentice Hall, CA, USA, 2010.

109. Cohen, J. Statistical Power Analysis for the Behavioral Sciences; Lawrence Erlbaum Associates: Hillsdale, NJ, USA, 1988.

110. Henseler, J.; Ringle, C.M.; Sinkovics, R.R. The Use of Partial Least Squares Path Modeling in International Marketing. In New Challenges to International Marketing; Cavusgil, T., Sinkovics, R.R., Ghauri, P.N., Eds.; Emerald Group Publishing Limited: Bingley, UK, 2009; pp. 277-319.

111. Zhao, X.; Lynch, J.G., Jr.; Chen, Q. Reconsidering Baron and Kenny: Myths and truths about mediation analysis. J. Consum. Res. 2010, 37, 197-206. [CrossRef]

112. Hayes, A.F. Introduction to Mediation, Moderation, and Conditional Process Analysis: A Regression-Based Approach; Guilford Press: New York, NY, USA, 2013.

113. Romani, S.; Grappi, S.; Bagozzi, R.P. Explaining consumer reactions to corporate social responsibility: The role of gratitude and altruistic values. J. Bus. Ethics 2013, 114, 193-206. [CrossRef]

114. Mancuso, I.; Natalicchio, A.; Panniello, U.; Roma, P. Understanding the Purchasing Behavior of Consumers in Response to Sustainable Marketing Practices: An Empirical Analysis in the Food Domain. Sustainability 2021, 13, 6169. [CrossRef]

115. German Carmakers Fined over Emissions ‘Cartel’, BBC News. Available online: https://www.bbc.com/news/business-57765113 (accessed on 17 July 2021). 